\title{
Impact of sustained professional development in STEM on outcome measures in a diverse urban district
}

Robert M. Capraro, Mary Margaret Capraro, James Joseph Scheurich, Meredith Jones, Jim Morgan, Kristin Shawn Huggins, M. Sencer Corlu, Rayya Younes \& Sunyoung Han

To cite this article: Robert M. Capraro, Mary Margaret Capraro, James Joseph Scheurich, Meredith Jones, Jim Morgan, Kristin Shawn Huggins, M. Sencer Corlu, Rayya Younes \& Sunyoung Han (2016) Impact of sustained professional development in STEM on outcome measures in a diverse urban district, The Journal of Educational Research, 109:2, 181-196, DOI: 10.1080/00220671.2014.936997

To link to this article: https://doi.org/10.1080/00220671.2014.936997

Published online: 18 Feb 2016.

Џll Article views: 716

View Crossmark data ¿
Submit your article to this journal $₫$
Q View related articles $₫$

4 Citing articles: 2 View citing articles 4 


\title{
Impact of sustained professional development in STEM on outcome measures in a diverse urban district
}

\author{
Robert M. Capraro ${ }^{a}$, Mary Margaret Capraro ${ }^{a}$, James Joseph Scheurich ${ }^{b}$, Meredith Jones ${ }^{a}$, Jim Morganc, \\ Kristin Shawn Huggins ${ }^{d}$, M. Sencer Corlu ${ }^{f}$, Rayya Younes ${ }^{f}$, and Sunyoung Han ${ }^{g}$
}

\begin{abstract}
aDepartment of Teaching, Learning, and Culture, Texas A\&M University, College Station, Texas, USA; Aggie STEM Center, Texas A\&M University, College Station, Texas, USA; ${ }^{\mathrm{b}}$ Department of Education, Indiana University - Purdue University Indianapolis, Indianapolis, Indiana, USA; ${ }^{\mathrm{C} D e p a r t m e n t}$ of Engineering, Charles Sturt University, Bathurst, NSW, Australia; ${ }^{d}$ Department of Education, Washington State University, Vancouver, Washington, USA; ${ }^{e}$ Bilkent University, Ankara, Turkey; ${ }^{\dagger}$ College of Education and Human Development, Radford University Radford, Virginia, USA; ${ }^{9}$ Department of Education, Sungkyunkwan University, Seoul, South Korea
\end{abstract}

\begin{abstract}
Sustained professional development can support STEM (Science, Technology, Engineering, and Mathematics) reform. The authors describe a 3-year study of sustained professional development for 3 diverse urban schools across the salient factors of fidelity of implementation of project-based learning, development of professional learning communities, and student achievement. Qualitative and quantitative data were collected. The students who experienced the greatest fidelity of implementation exhibited the greatest gains $(d=1.41-2.03)$ on standardized test scores, while those with the lowest fidelity of implementation exhibited negative gains $(d=-0.16$ to -0.08$)$. Qualitative data indicated teachers perceived there were multiple benefits from the implementation of project-based learning.
\end{abstract}

ARTICLE HISTORY

Received 27 October 2013

Revised 5 May 2014

Accepted 14 June 2014

\section{KEYWORDS}

High school; mathematics; professional development; project-based learning; science; urban schools
Although STEM (Science, Technology, Engineering, and Mathematics) has been diversely defined by various researchers (e.g., Buck Institute for Education, 2003; Capraro, Capraro, \& Morgan, 2013; Scott, 2009; Wolf, 2008) during the last decade, STEM education has gained an increasing presence on the national agenda through initiatives from the National Science Foundation and the Institute for Educational Sciences (IES). Several states, such as Texas and Ohio, have also initiated statewide STEM efforts focused on preK-12 schools (Herzog, 2010). Additionally, STEM has attracted private sector interest from diverse groups, such as the Bill and Melinda Gates Foundation, the Houston Endowment, the Society of Manufacturing Engineers, and the American Association of University Women (Berry et al., 2004; Dyer, 2004; Toulmin, \& Groome, 2007). Furthermore, a major national report, Rising Above the Gathering Storm (National Academies, 2007), prepared by leading participants from academia, corporations, and government, has garnered considerable attention.

That report was released at a time of growing concern over the future of the United States in an increasingly globalized and competitive world, particularly in relation to the demand for workers proficient in science and technology (National Academies, 2007). The Committee examined existing research and trends regarding the science and technology enterprise in the United States and developed specific recommendations. The summary painted a solemn picture, expressing its concern that "the scientific and technological building blocks critical to our economic leadership are eroding at a time when many other nations are garnering strength" (National Academies, 2007, p.
3). Particularly noted were inadequacies in science and mathematics education, deficiencies in research funding, and economic policies that stifle innovation in science and technology as factors limiting the number of qualified workers and threatening the future prosperity of the United States.

To remain competitive, the Committee recommended that the United States optimize "its knowledge-based resources, particularly in science and technology" (National Academies, 2007, p. 4). Recommendations included calls for increased recruitment of science and mathematics teachers, expanded teacher education, promotion of the STEM pipeline through K-12 education, greater research funding, and adoption of economic policies that would foster innovation in mathematics and science. While the report attracted widespread attention, it also has received some criticism from individuals who said it portrayed a more severe situation than the data warranted. For example, Lowell and Salzman (2007) argued that existing data indicated that the performance of U.S. students in mathematics and science is actually improving or has remained stable and that the current system is producing more qualified graduates in science and engineering than there are open positions for these graduates to fill. Schools are starting to evaluate their own education systems and examining strategies that will increase the overall quality of STEM education to prepare students for jobs in a 21st century workforce. Researchers need to guide high schools by providing research that supports increasing the rigor of high school curriculum, addressing the needs of students who are college-bound, and improving excellence in teaching and leadership within schools. Thus the researchers 
involved in this study were guided by the following research questions:

Research Question 1: What was the impact of sustained and systemic professional development (PD) on classroom enactments of project-based learning (PBL) on teacher enactments of STEM PBL in three urban high schools?

Research Question 2: What effect does classroom implementation level have on student outcome measures?

Research Question 3: What were the teachers' perceptions of their experience when (a) implementing PBLs in their classrooms, (b) implementing professional learning communities, and (c) receiving PD on the implementation of PBLs and professional learning communities?

\section{STEM and education}

In recent years, concern about the mathematics and science achievement of U.S. students has led to increasing interest in STEM education. Cross-national comparison data have shown that U.S. students lag behind many other nations in student proficiency in mathematics and science, and data regarding degree attainment has shown that U.S. students receive fewer degrees in mathematics and physical sciences than students in many other countries (National Academies, 2007). In addition, while the overall proportion of STEM degrees attained by U.S. students has remained fairly constant (approximately 17\% of all degrees received), other nations have seen more rapid growth in receipt of STEM degrees (Kuenzi, 2008). Data indicate lower levels of enrollment in mathematics and science courses among students of color in K-12 education and a lower retention rate in STEM majors in college (Museus, Palmer, Davis, \& Maramba, 2011). In response, there has been a growing effort to promote STEM education and to encourage U.S. students' achievement in STEM areas (Kuenzi, 2008). These efforts to promote STEM education are evident in the numerous federal and state initiatives and standards that aim to provide funding and support for STEM education (MoyerPackenham, Kitsantas, Bolyard, Huie, \& Irby, 2009).

STEM PBL activities are supported by the Common Core State Standards (CCSS), the Next Generation Science Standards (NGSS), and the Texas Essential Knowledge and Skills (TEKS). When working on STEM PBL students follow the key components of engineering design, one of the key components of the NGSS (National Research Council, 2013) through researching, reasoning, listening to other students' ideas, persisting until an artifact is created, being able to critique other students' ideas, revising, and deciding on appropriate tools and strategies (National Governors Association Center for Best Practices Council of Chief State School Officers, 2010). The TEKS address STEM content through student expectations for courses in all four of the STEM areas that can be related to STEM PBL (Texas Education Agency, 2013). In addition, the TEKS are closely aligned to the college and career readiness standards that are also well suited to STEM PBL instruction (Texas Higher Education Coordinating Board, 2009). Two cross-cutting objectives common to all three are the following: (a) Students will communicate ideas, reasoning, and their implications using multiple representations such as symbols, diagrams, graphs, and language and (b) students will generate solutions and make connections and predictions. More generally, TEKS statements include phrases or terms real-world problem-solving, or problems arising in everyday life to specify that problems students solve should include contextual situations. Similar to the TEKS, the CCSS Standards for Mathematical Practice are based on the NCTM Process Standards and the NGSS include connections within and outside of a single subject matter. In mathematics, the CCSS for mathematics focus on problem solving specifying that students can apply what they know to solve problems arising in everyday life, society, and the workplace.

Efforts to promote STEM education have also been facilitated through collaboration between universities and $\mathrm{K}-12$ schools (Moyer-Packenham et al., 2009). Such efforts have taken several forms including PD for in-service teachers and STEM programming for $\mathrm{K}-12$ students. Collaborative centers have also been established to facilitate partnerships between higher education institutions and $\mathrm{K}-12$ schools, where university centers partner with school districts to provide STEMoriented in-service education (Hailey, Erekson, Becker, \& Thomas, 2005).

\section{Sustained professional development}

The present literature regarding the effects of teacher PD on student achievement outcomes indicates differential effects depending on the quality and the specific features of PD provided. Findings indicate that high-quality sustained teacher PD typically has statistically-significant positive effects on teaching practices and student outcomes (Garet, Porter, Desimone, Birman, \& Yoon, 2001; Guskey \& Yoon, 2009; Nadelson et al., 2013; Supovitz \& Turner, 2000Wei, Darling-Hammond, \& Adamson, 2010; Yoon, Duncan, Lee, Scarloss, \& Shapley, 2007). However, research has shown that many teachers do not experience high-quality PD, and these less effective PD experiences may have negligible effects on student achievement (Desimone, Porter, Garet, Yoon, \& Birman, 2002; Wei et al., 2010).

Nonetheless, a substantial body of research has demonstrated that teacher PD can benefit student achievement. For example, a longitudinal, quasi-experimental study by Saunders, Goldenberg, and Gallimore (2009) compared nine Title I schools receiving PD to six control schools in the same district and found that the PD schools had greater achievement growth on three years of state-mandated testing. These findings have been supported by previous research, which showed that teacher participation in PD is associated with continuous growth in state assessment scores across the years and increases in students' academic achievement (Cohen \& Hill, 2000; Czerniak, Beltyukova, Struble, Haney, \& Lumpe, 2005; LoucksHorsley, Love, Stiles, \& Mundy, 2003; Schneider, Krajcik, Marx, \& Soloway, 2002).

Several characteristics of effective PD have been identified in the research (Guskey, \& Yoon, 2009). In their longitudinal study, Desimone et al. (2002) identified six key features of PD, including three structural features (reform type, duration of $\mathrm{PD}$, and collective participation) and three core features (opportunities for active learning, coherence, and content focus). Additionally, several studies have shown that the most 
effective PD is intensive and sustained (Garet et al., 2001; Guskey \& Yoon, 2009; Supovitz \& Turner, 2000; Yoon et al., 2007). K. Johnson, Hays, Center, and Daley (2004) defined sustainability as the "continued ability of an innovation (infrastructure or program) to meet the needs of its stakeholders" (p. 137). The primary factor associated with statistically-significant positive outcomes was 14 or more hours of PD. Studies that provided fewer than $14 \mathrm{hr}$ of $\mathrm{PD}$ did not have statistically significant effects on student outcomes (Yoon et al., 2007)

Further research is needed, though, to examine the connection between the impact of PD on teacher knowledge and practices and enhanced student outcomes (Penuel, Fishman, Yamaguchi, \& Gallagher, 2007; Yoon et al., 2007). In a research synthesis of PD effectiveness, there was a limited number of methodologically rigorous studies (Yoon et al., 2007). Studies, such as the one presented here, that take place in real world classroom settings and that make of use sophisticated statistical techniques to relate teacher classroom behaviors due to sustained PD to student achievement will strengthen the evidence base in this area.

To obtain sustainable innovation-based improvements in student achievement, change must be established systemically at the school level (Resnick \& Hall, 1998). Research shows that the key elements in building and maintaining this cycle of sustainable growth at the school level are the type and duration of PD provided to teachers and the extent to which they participate in communities of practice (Smylie, Allensworth, Greenberg, Harris, \& Luppescu, 2001). Whole school sustained PD programs that are supported by focused collaboration among teachers will likely result in improved instructional practice (Hart \& Lee, 2003; C. C. Johnson, Kahle, \& Fargo, 2007).

\section{Professional learning communities}

In an era of standards-based accountability (No Child Left Behind Act of 2001, 2002), improving instruction to increase student achievement is of paramount importance. Within organizational learning theory, expanding capacity, increasing new ways of thinking, and learning how to learn together (Senge, 1990) are mutually supportive and intertwined resulting in systemic school improvements. Professional learning communities provide organizations, such as schools, with a research-supported way of increasing organizational learning (Argyris \& Schön, 1978; Hedberg, 1981). Professional learning communities can be characterized by several factors, including shared beliefs, values, and vision; shared and supportive leadership; collective learning; supportive conditions; and shared personal practice (Hord \& Sommers, 2008) in which administrators and teachers continuously learn together (Hord, 1997).

There are two core beliefs that are foundational, though, to the application of professional learning communities in schools. The first belief is that the day-to-day experiences teachers share within the school assist them in helping their colleagues improve practice (Buysse, Sparkman, \& Wesley, 2003). The second belief is that teachers who have time for collaboration are able to improve their practice more than they would in isolation, by obtaining and using the knowledge of their colleagues (Talbert \& McLaughlin, 2002). Accessing collective knowledge is particularly important in PD situations where teachers may be asked to adopt pedagogical changes that are foreign to what they have experienced or how they have previously taught (Darling-Hammond \& McLaughlin, 1995).

Because many schools struggle with the adoption of new pedagogy, some professional learning communities have been created to engage teachers in new ideas and methods within a supportive context (e.g., Englert \& Tarrant, 1995; Hollins, McIntyre, DeBose, Hollins, \& Towner, 2004). In fact, multiple professional learning communities, including cross school, school based, and within school have been implemented to achieve pedagogical change (e.g., Englert \& Tarrant, 1995; Hollins et al., 2004; Huggins, Scheurich, \& Morgan, 2011; Louis \& Marks, 1998). Such pedagogical change often involves innovative instructional approaches that are intended to improve teaching and learning for diverse low socioeconomic status and underachieving students (Hollins et al., 2004; Phillips, 2003). One study (Hollins et al., 2004) showed how teachers who participated in professional learning communities over a two-year time period improved the literacy acquisition and development of African American elementary students. Indeed, professional learning communities have been found to maximize time spent in PD in several different socio-demographic contexts (e.g., Cochran-Smith \& Lytle, 1999; Louis, Kruse, \& Marks, 1996; Louis \& Marks, 1998). However, most of the research has examined professional learning communities at elementary and middle grades with only a few published studies focusing on high school (Huggins et al., 2011; Louis et al., 1996; McLaughlin \& Talbert, 2001) and even fewer specifically addressing STEM issues in sustained PD (Darling-Hammond, Wei, Andree, Richardson, \& Orphonos, 2009).

\section{STEM project-based learning}

The etiology of STEM PBL can be traced back to the origin of problem-based learning. The origin of problem-based learning was firmly rooted in the preparation of physicians. Patients possess a set of symptoms and the goal of modern medicine is to, as quickly as possible, arrive at the most likely diagnosis and commence treating or to employ a test to rule out that likely diagnosis (Flexner, 1910). The main purpose was to create a parsimonious yet robust solution set involving convergent thinking. As engineering gained prominence after the first engineers were appointed in the military by President Washington circa 1775, both in formal apprenticeships and university preparation, convergent thinking was dominant. As engineer preparation became more formalized in colleges and universities, there was a movement in the late 1800 's to reduce shop hours where engineers sought parsimonious and convergent solutions to science that fostered divergent yet robust solutions based on constraints (Thurston, 1891, 1892). Educationally, there was a great deal of emphasis on projects that were comprised of identifying needs and solving all problems that arise from the given solution path (Kilpatrick, 1918; Noyes, 1909). The education movement is often credited as having given rise to the idea of engineering design where classrooms rich in projects lead students to use reasoning skills (Wilhelm, Sherrod, \& Walters, 2008). Given this rich history, STEM PBL makes heavy use of the engineering design process, where multiple and 
diverse solutions are accepted and valued. The project is governed by constraints and assessed by milestones (Polman, 2000) or rubrics that honor the inter/trans disciplinary nature of engineering. Final projects in which students accurately represent concepts (Wilhelm, Sherrod, \& Walters, 2008) are often presented in writing, orally, or in other media as product marketing, funding solicitation, or commercialization.

STEM PBL was been defined as a "well-defined outcome with an ill-defined task" (Capraro, Capraro, \& Morgan, 2013, p. 2) within an interdisciplinary framework. These ill-defined tasks can be complex and messy by nature (Bridges \& Hallinger, 1996; Torp \& Sage, 1998). With ill-defined projects, students investigate interdisciplinary, rigorous, real-world topics (Chin \& Chia, 2006) that usually stem from a driving question or issue (Blumenfeld et al., 1991; Krajcik, Blumenfeld, Marx, \& Soloway, 1994). According to Holbrook, Rannikmae, \& Valdmann (2014), project-based learning has been defined as a model for classroom activity where the focus on the teacher is diminished and the focus on student activity is increased with a greater emphasis on long-term interdisciplinary and integrated addressing of real-world issues in a practice-based format. PBLs comprise many aspects and a variety of content combinations. ${ }^{1}$

In addition, research has shown that students learn better when they are engaged in meaningful activities (Fortus, Krajcik, Dershimer, Marx, \& Mamlok-Naaman, 2005; Hancock \& Betts, 2002) that produce authentic artifacts (Hung, Tan, \& Koh, 2006). Accordingly, using real-world problems within PBLs makes knowledge more relevant for students and increases the transfer of skills and information from the school setting to the real world (Bransford, Brown, \&
Cockling, 2000; Colburn, 1998; Curtis, 2001; Satchwell \& Loepp, 2002), thus promoting life-long learning (Dunlap, 2005).

There have been several studies examining the effects of PBL on student achievement. Students who participated in PBL units showed significantly higher pass rates on high stakes testing, demonstrating the efficacy of PBL for reducing the achievement gap for urban African-American males (Geier et al., 2008). PBL instruction resulted in students demonstrating higher levels of comprehension and application of concepts compared to when the same content was taught using a lecture format (Sungur \& Tekkaya, 2010; Wirkala \& Kuhn, 2011). It was also found to improve science academic achievement for students from disadvantaged backgrounds (Lee, Buxton, Lewis, \& LeRoy, 2006). In addition, developing PBLs within professional learning communities made the adoption process go more smoothly (Krajcik et al., 1994). When qualitative studies were meta-synthesized it was shown that PBL instruction was more effective than traditional instruction to promote longterm retention of knowledge and skills (Strobel \& van Barneveld, 2009).

Implementing STEM PBL has trade-offs. For example, while teachers valued PBL, they felt that the constraints of time, schedules, materials and facilities hindered their ability to fully implement PBL (Bradley-Levine et al., 2010). Another tension was that teachers struggled with implementation of STEM PBL because they felt accountable for delivering a standards-based curriculum to prepare students for end of year exams and standardized tests. One final tension was that teachers who were more content/achievement focused opposed to career skills focused had difficulty because they were not able to use traditional measures of

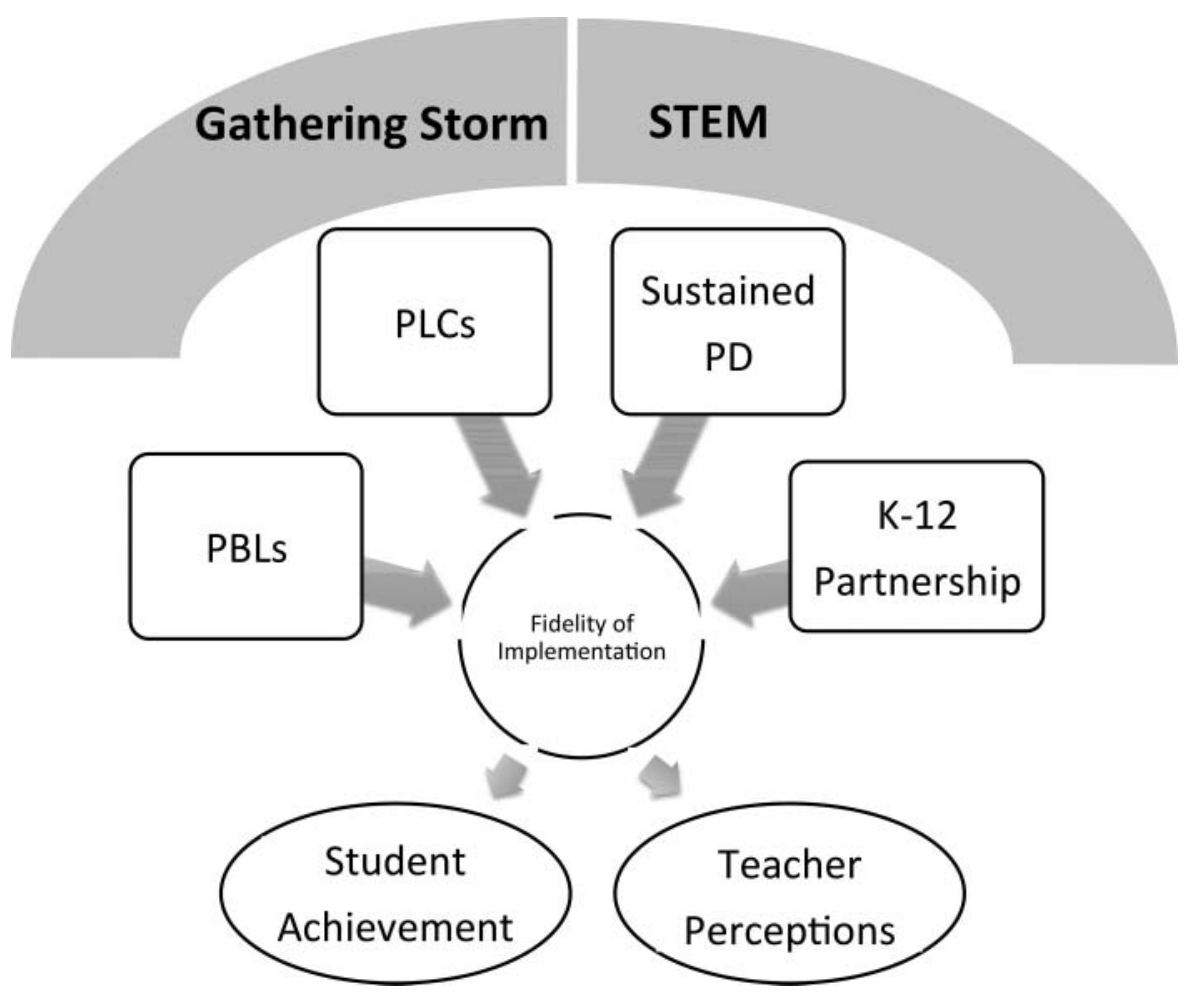

Figure 1. Theoretical framework/logic model. 
student achievement as a success indicator (Rodgers, Cross, Gresalfi, Trauth-Nare, \& Buck, 2011). Therefore, the tensions arose from time constraints, accountability, and personal paradigms.

\section{Philosophical perspective and framework}

Figure 1 summarizes our framework in terms of a logic model. The message in the Gathering Storm supports our purpose and context for improving STEM education particularly at the high school level through sustained professional development (input). While various strategies have been tried and some studied (as discussed previously), there is still a substantial deficiency in this area. In the current research reported here, the following activities were provided: an intervention of sustained PD provided by a university-based team of professors and graduate students working with high school educators on STEM PBL with the support of professional learning communities was studied in terms of fidelity of implementation (short term outcome) and ultimately in terms of effects on student achievement as measured by state accountability tests and perceptions of teachers on how the PD effected their classroom instruction (long term outcomes). Thus, the systemic intervention in terms of a logic model studied here examined how professional learning communities can support PD with teachers in developing STEM PBLs and how that unique pedagogical innovation influenced both student achievement and teacher perceptions especially in mathematics and science (see Figure 1, which summarizes our logic model framework for this study).

\section{Method}

The present study was a longitudinal investigation of urban secondary STEM PBL and professional learning community PD using propensity score matching to compare two groups of students per school. In addition, longitudinal observational data were collected, and focus group interviews were conducted to better describe the effects. Student achievement on a state highstakes test was used as an indicator of the effectiveness of the model because of the systemic and comprehensive nature of the implementation.

\section{Study demographics}

This study was conducted in an independent school district within a mid-sized urban area (population of 120,000 ) with an enrollment of 15,171 students. The district has 20 elementary schools, seven middle schools, and three high schools and largely serves a low-income population, with $83.1 \%$ of the students classified as economically disadvantaged. The demographics of the student body included 34.9\% Black, 50.9\% Hispanic, and $13.6 \%$ White. Additionally, $14.4 \%$ of the students were classified as limited English proficient, $11.4 \%$ as special education, and $13.14 \%$ as bilingual/English as a second language. The state education agency accountability system assigns different ratings based on the performance of the particular school, including standardized test scores and graduation rate. Schools may receive one of four rankings including: recognized, acceptable, academically unacceptable, and not rated. During the first school year (inception of the study), 75\% of the district students met state standards and nine campuses in the district were rated as "recognized" by the state education agency. The district had a high school completion rate of $85 \%$, according to the state's measurement of completion. The study took place in all three-district high schools with a total student population of 1,185 in Grade 9, 943 in Grade 10, 923 in Grade 11, and 750 in Grade 12. During the first study year, all three high schools were rated as academically acceptable by the state education agency. The salient teacher background variables are contained in Table 1. Proportionately, the schools had similar ethic composition and years completed for teachers.

\section{Intervention}

A systemic, district-level initiated intervention occurred, consisting of three components: (a) PD delivered for a three-year period with 10 set days $(60 \mathrm{hr}$ per year, for a total of $180 \mathrm{hr}$ over the course of the study using a fixed set of PD providers, (b) development of professional learning communities, (c) classroom observations of PBL implementation within each school coupled with research-based PD for implementing professional learning communities. Classroom observations of PBL implementation and feedback were conducted throughout the three-year duration of the study. Baseline observations of PBLs were conducted before study inception by the research team. Initially the scope and sequence was arranged by best practices and then by needs assessment and careful analysis of proximal measures (such as benchmarking tests, teacher-made tests, and school-developed just-in-time measures) of school district change, including the results of the observations. The proximal measures were used solely to examine specific aspects of the intervention and changed over time, thus no stable estimates over time exist for those measures and will not be reported here.

The participants consisted of science, technology, engineering, and mathematics teachers at three high schools $\left(n_{\text {schooll }}\right.$ $=20, n_{\text {School } 2}=25, n_{\text {School } 3}=11$ ). Classroom observation data were used to directly measure the quality of classroom implementation of the PBL PD, and student scores on the state's high-stakes test were used as a measure of value added attributed to the teachers' implementation of the PD. The PBLs that were developed varied by discipline and covered many topics. The focus of the PBL content was on learning objectives where students scored low historically: measurement and problem solving in mathematics and science process skills and motion

Table 1. Salient teacher participant background information.

\begin{tabular}{|c|c|c|c|c|c|c|c|c|c|c|c|c|}
\hline \multirow[b]{2}{*}{ Ethnic group } & \multicolumn{4}{|c|}{ HS1 } & \multicolumn{4}{|c|}{ HS2 } & \multicolumn{4}{|c|}{ HS3 } \\
\hline & $\mathrm{F}$ & BA & MA & $\mathrm{Y}$ & $\mathrm{F}$ & BA & MA & Y & $\mathrm{F}$ & BA & MA & $Y$ \\
\hline Asian & 1 & 1 & 0 & 1 & 0 & 0 & 0 & 0 & 0 & 0 & 0 & 0 \\
\hline Black & 4 & 4 & 2 & 3 & 3 & 5 & 1 & 3 & 4 & 6 & 0 & 3 \\
\hline Hispanic & 3 & 6 & 1 & 7 & 5 & 6 & 0 & 4 & 5 & 5 & 1 & 3 \\
\hline White & 4 & 2 & 3 & 7 & 5 & 7 & 3 & 4 & 2 & 3 & 0 & 4 \\
\hline Other & 1 & 0 & 1 & 6 & 2 & 2 & 1 & 1 & 1 & 1 & 1 & 4 \\
\hline Total & 13 & & 0 & 5 & 15 & & 25 & 3 & 12 & & 17 & 3 \\
\hline
\end{tabular}

Note. Data from initial year of the study. $\mathrm{F}=$ female. No teacher held a PhD or EdD, degree (BA or $\mathrm{MA}$ ) was highest held in field, $\mathrm{Y}=$ weighted mean years completed at that school. No teacher was out of field in mathematics or science. 
and energy. The lesson plans are lengthy and not contained here (for samples see Capraro, Capraro, Morgan, \& Scheurich, 2010). Topics of the PBLs ranged from finding the applications for geometric figures found around their school community, finding the optimal area for cages in the local zoo, determining which summer jobs to apply for that allows students to make the highest salaries with the constraints of cost of transportation and uniforms, designing a trebuchet that will toss the heaviest object the farthest, determining the greatest sources of pollution in their school community and develop a remediation plan, assuming a zombie apocalypse what would be the necessities to assure survival, designing a car that travels the fastest given a ramp. Most of the PBLs were developed and access was provided across the school district during the professional development. The school district's curriculum specialists ensured that the STEM PBLs were placed into the district share box and assisted with fidelity of implementation.

\section{PD framework}

The PD program was initially designed to meet the needs of the district, school administration, and teacher participants. In some cases, these initial goals were not well aligned among the stakeholders, and thus it was the responsibility of the PD providers to guide and merge the expectations of the stakeholders into a coherent PD plan. The resultant PD plan provided a coherent and systemic scope and sequence (yet with sufficient flexibility to accommodate emergent needs in subsequent years) for the three years (total of 30 days of PD) focused on STEM PBL pedagogical strategies, professional learning communities, and STEM content knowledge focusing on algebraic concepts most frequently missed and scientific process skills, motion, and energy. The district plan was to provide training for all teachers to increase awareness and understanding and to encourage support for interdisciplinary PBLs. Training was provided to a consistent set of 75 STEM teachers over the three-year period, however, periodically special education teachers, pull-out coaches, language arts, and art teachers participated. Their participation often depended on the topic. The agenda was provided to teachers 5 days in advance of each PD. Each PD was led by a single team member with support from other team members to facilitate small group interaction. A strict ratio of 10 teachers to one PD specialist was maintained throughout the three years. The PD titles specific to STEM PBL were (a) STEM PBL structure, (b) STEM PBL facilitation, (c) student participation, (d) resources, (e) assessment, and (f) STEM classroom learning environment (cf. Stearns, Morgan, Capraro, \& Capraro, 2012). The sustained and systemic PD planning included the needs of all stakeholders, the delivery methods, assessment, and observations that were used for planning each year.

Other topics covered during the sustained PDs covered: defining STEM and PBL, interdisciplinary STEM PBLs, the engineering design process, covering state standards while implementing PBL activities, classroom management considerations including grouping of students, questioning techniques, designing rubrics, formative and summative assessments, seamlessly integrating technology into PBLs, developing PBLs for high school classrooms, and professional learning communities.
A book on STEM PBL (Capraro \& Slough, 2008) was provided to the teachers as a reference guide.

The PD process included iterative and recursive planning and implementation phases that assisted with designing subsequent PD sessions. During the planning phases, the stakeholders participated in discussions about what was and was not working, planned activities, and allotted days to specific topics. They examined their own content knowledge and brought issues and concerns to their leadership teams and then PD was designed to address those concerns. Both strengths and weaknesses were discussed with strengths incorporated into professional learning community time and weaknesses addressed initially during formal PD by the provider. The initial year of PD focused on PBL-related pedagogy; ways to incorporate immediate response technology, calculators, and interactive whiteboards within the PBL classroom; and setting up professional learning communities. The PDs were designed to help teachers integrate PBLs within their classrooms with a focus on PBL structure, PBL facilitation, and creation of a STEM supportive classroom-learning environment. The second year of PD focused on student engagement, managing PBL resources, and conducting assessments. The third and final year of PD provided advanced coverage of the same topics, while also helping teachers develop plans for sustaining the innovation through their professional learning communities. Throughout the three years, teachers developed and taught one STEM PBL each grading period and shared their lesson plans through an electronic repository. STEM PBLs consisted of between five and seven lessons taught noncontiguously based on four tenets (e.g., Capraro et al., 2013): (a) active engagement, (b) projects are comprised of a well define outcome but an ill-defined task that requires students to develop and solve multiple problems with divergent solution sets, (c) student ownership of learning, and (d) multiple seamless formative and summative assessments.

\section{Observations - Fidelity of implementation and teacher implementation data}

Teachers developed lessons that met the needs of their students based on prior student performance on district assessments. Therefore, three schools, seven subject courses across mathematics and science, eight grading periods per year, for three years equaled 378 STEM PBLs. Not all STEM PBLs were unique, some teachers borrowed one lesson framework and modified it to address their objectives of interest. Because teachers were addressing content in their classrooms broadly with one STEM PBL addressing potentially $6-8$ objectives characterization of the lessons across this broad a spectrum would over generalize.

A teacher observation instrument was developed to measure the alignment of the PD to teachers' classroom enactments of PBL with their students (Stearns et al., 2012) containing twenty-two items (indicators) organized into six categories, including: (a) lesson structure, (b) lesson facilitation, (c) student participation, (d) resources, (e) assessment, and (f) classroom learning environment. The number of indicators under each category varies. Each item can be evaluated on a 5-point Likert-type scale ranging from 0 (no evidence) to 5 (to a great 
extent). The observer must justify every score assigned to each item. Occasionally, an item will not apply to what is taught during a particular observation. This may happen if the observer is only present for part of a lesson. However, well-documented lesson plans available prior to the observation typically provided insight and additional information that allowed an item to be evaluated even if not directly observed. Nonetheless, the observer may still choose to indicate that a particular behavior (item) was not applicable or not observed during the class period.

\section{Data analysis and participants}

The data collected consisted of raw scores on the state accountability instrument for mathematics, science, and language arts (reading), teacher observations, and focus group interviews with teachers and administrators. To address the potential issue of high student mobility (38\% during the first year of data collection), a target population needed to be identified that consisted of the students most likely to be retained in the same school for three years, (i.e., Grade 9 through exit level taken in Grade 11). Students who were members of the following groups were omitted from the study due to the potential for high mobility or attrition: at-risk status, which included migrant, learning disabled, or early parenthood (Freudenberg \& Ruglis, 2007; Gibson \& Hidalgo, 2009; Morrison \& Codsen, 1997). Also omitted from participation were students who were nonEnglish proficient (cf. Ashby, 2010) and students receiving services that supplanted regular mathematics or science instruction, because these students were not likely to receive the intended program. Based on these criteria, $27 \%$ of the student population at the three high schools was excluded from the target population. The remaining $73 \%$ of students served as the target population for the study, which, nonetheless, was a highly diverse group primarily from low-income families. Without this adjustment, it would not have been possible to have a reasonably stable longitudinal study population. This initial selection comprised the student scores for each of the three years.

Teachers were the target population participating in the professional development. First, teachers' level of PBL implementation was estimated by the classroom instruction observation instrument (Stearns et al., 2012). This resulted in high and low level implementers at each school. For the purposes of this categorizing, high and low were artifacts of each school and not overall across schools. Generally, teachers were tightly grouped above or below the mean for the school. Teachers above the mean constituted the high group while those below constituted the low group (high school 1 [HS1] $=7$ above, 6 below; HS2 $=8$ above, 8 below; HS $3=$ 5 above, 6 below). Mathematics and science teachers planned together and implemented different parts of the same PBL in their individually subject-focused classrooms. All teachers were all highly qualified by federal and state definition, had earned traditional teacher certification and on average had 4.32 years teaching ( $S D=6.21$ years).

Because both mathematics and science classes were implementing the program, the simple arithmetic mean level of implementation was used across mathematics and science to select the student sample. The sample of interest ( $n=60)$ was randomly selected from this population. The matched population consisted of the students who were enrolled in Grade 9 in teachers' classes who demonstrated the lowest level of STEM PBL enactments based on classroom observations at each school, that is, below the mean at each school. The simple arithmetic mean was used across mathematics and science classes. The matched sample $(n=$ 60) was selected using propensity score matching to the longitudinal group using one-to-one, nearest neighbor matching (Dehejia \& Wahba, 2002) at each school. Student academic performance was matched in the selection process as well as for the courses the students had taken. This allowed for intraschool comparisons based on students' initial induction into the program. Because initial experience in Grade 9 often sets student academic expectations for the remainder of high school, there was interest in Grade 9 students and those teachers whose implementations were at the high and low extremes. In this regard, we expected that students might be influenced by their initial experiences (Cooper \& Liou, 2007). Whereas, all the students would likely experience the average level of implementation at the school over the duration of the study, we wanted to be able to determine the relative importance of average fidelity within each school while comparing the highest and lowest initial implementation at each high school without introducing inter-school variance. That is, comparing schools introduces salient and substantial factors (e.g., school climate, administrator factors, school curriculum) that could not be modeled nor controlled (Shadish, Cook, \& Campbell, 2012).

\section{Quantitative research}

Data were gathered for the year prior to the beginning of the project and for the next three successive years while teachers participated in the PD. Data from the state's high-stakes accountability instrument were used to determine the gross improvement. The raw Texas Assessment of Knowledge and Skills (TAKS; the state's accountability exam) scores for all three years were $0-54$ (reading), $0-55$ (science), and 0-59 (mathematics). The project was not intended to effect reading scores so reading scores were included as an estimate of overall change and as an indicator to determine whether some other factor may have been responsible for the observed changes. Therefore, only science and mathematics scores were expected to be sensitive to the innovation. For example, if reading scores were correlated with the mathematics and science scores, this would indicate contamination of the results. In addition, reading scores uncorrelated or disassociated with mathematics and science would indicate that the anticipated observed effect could be attributed to the innovation.

Data were collected on the quality of PBL implementation throughout the study using the observation instrument (Stearns et al., 2012). Research personnel received training in how to conduct observations using the observation instrument and subsequently conducted observations (contact the authors for a 
copy). Interrater reliability was calculated using mixed pairs (James, Demaree, \& Wolf, 1984) conducting simultaneous observations and reconciling immediately following the observation. The mixed-pairs model ensured the raters did not become consistent among themselves while becoming totally different from other raters. The mixed-pairs model also ensured that each rater rated a different teacher and lesson with a unique partner for the purpose of calculating consistency. The inter-rater reliability was $100 \%$ agreement after reconciliation ( $97 \%$ before). The mean level of implementation was calculated based on the full instrument to answer the research questions.

\section{Qualitative research}

Qualitative research is generally used to gather the experiences or perspectives of one or more individuals (Lincoln \& Guba, 1985; Marshall \& Rossman, 2006). Accordingly, the spoken or written words of these individuals become the data for qualitative work (Creswell, 2009). The most common method for collecting qualitative data is through interviews, which occur either in group or individual settings (Kvale \& Brinkmann, 2009). In this study, the qualitative data were drawn from focus group interviews conducted with teachers. Patton (2002) described focus group interviews as "an interview of a small group of people on a specific topic" (p. 385). The size of the group, length of the interview, and the degree of interview structure, however, may vary.

In the present study, the size of the focus groups ranged from four to ten teachers with interviews lasting between 60 and $90 \mathrm{~min}$ in duration. All three qualitative researchers followed the same set of sequenced questions during the interview. The groups were conducted separately with mathematics teachers only or science teachers only at each of three high schools. This resulted in six focus group interviews conducted by three researchers. All of the interviews were digitally recorded.

The interview questions addressed the positive and negative experiences participants had with the sustained PD on STEM PBL, implementation of PBLs, and their professional learning communities. Specifically, the questions addressed such topics as the positives and negative aspects of the PD on STEM PBL and professional learning communities, the implementation of STEM PBL in their classrooms, the reactions of their students to $\mathrm{PBL}$, and the implementation of professional learning communities.

After conducting the focus group interviews, the next step was to analyze the data. Typically, interview data are coded in small chunks of words that have meaning for the researcher in reference to the study. These coded chunks are then combined into logical categories, followed by aggregating categories into themes (Lincoln \& Guba, 1985; Miles \& Huberman, 1994; Patton, 2002). Because in this study all interviewers followed the same sequence of questions, a more simplified approach was employed. An innovative software program, Microsoft OneNote (Microsoft Corporation, Redmond, WA) was used instead of the more traditional approach of transcribing all of the interviews for data analysis (Silverman, 2010). Microsoft OneNote enables listening to an audio recording and type notes while listening. The notes are digitally connected or keyed to the specific part of the interview that is being listened to on the recording when the note is typed. When a specific quote from the interview is needed, it is possible to return via the code to the recording and just transcribe the segment needed. While this transcribing process might not work with more unstructured, complex interview material, it worked well in this study because of the structured interview format.

In this study, each interviewer listened to her or his recordings, coded the responses to each question, and then categorized the codes for each question when a higher level of abstraction was warranted. The next step was aggregating and thematizing the codes and categories of all three interviewers by the group. This process resulted in the identification of six themes.

\section{Results}

\section{Quantitative}

The observation instrument results showed that by the third year of the innovation, there was marked improvement in mean scores for each of the six categories from baseline observations in the year prior to study inception through the next three years. The longitudinal observation results indicated that mean observational patterns emerged within schools clearly disaggregated by level of implementation. HS3 demonstrated the highest mean scores of indicators, followed by HS2 and HS1. Teachers in HS1 showed the lowest implementation level, which was typified as the mean of most indicators being below 2.5 and called level 1. Teachers in HS2 demonstrated mean scores of indicators clustered around 2.5, which was designated a middle implementation and termed level 2. Teachers in HS3 had the highest implementation level that was typified by a mean of 3.5 and the means of all indicators being above a 2.5, which was considered a high implementation level of the intervention and called level 3. For a complete reporting of the characteristics at each level please see Stearns et al. (2012).

HS1. The teachers in this school $(n=20)$ demonstrated a level one implementation with the mean of all but one indicator

Table 2. Means, standard deviations, and effect sizes by school and content.

\begin{tabular}{lcccrr}
\hline Group & Content & Y1 & Y4 & \multicolumn{1}{c}{ SD } & Effect size \\
\hline HS1-M & Science & 26.19 & 29.72 & 15.96 & 0.22 \\
HS1-L & Science & 26.22 & 25.71 & 6.35 & -0.08 \\
HS1-M & Mathematics & 33.42 & 38.98 & 16.51 & 0.34 \\
HS1-L & Mathematics & 33.59 & 32.23 & 8.49 & -0.16 \\
HS1-M & Reading & 36.17 & 24.35 & 24.72 & -0.48 \\
HS1-L & Reading & 36.55 & 38.91 & 9.22 & 0.26 \\
HS2-M & Science & 19.01 & 19.72 & 17.86 & 0.04 \\
HS2-L & Science & 18.98 & 25.91 & 9.53 & 0.73 \\
HS2-M & Mathematics & 28.6 & 26.29 & 10.04 & -0.23 \\
HS2-L & Mathematics & 28.66 & 34.39 & 8.74 & 0.66 \\
HS2-M & Reading & 29.2 & 24.75 & 12.58 & -0.35 \\
HS2-L & Reading & 29.13 & 27.64 & 4.33 & -0.34 \\
HS3-M & Science & 22.64 & 37.85 & 16.50 & 0.92 \\
HS3-L & Science & 22.5 & 35.89 & 6.61 & 2.03 \\
HS3-M & Mathematics & 21.16 & 34.55 & 21.69 & 0.62 \\
HS3-L & Mathematics & 21.25 & 33.51 & 8.68 & 1.41 \\
HS3-M & Reading & 25.42 & 24.24 & 14.71 & -0.08 \\
HS3-L & Reading & 25.33 & 28.29 & 8.15 & 0.36 \\
\hline
\end{tabular}

Note. SD is the pooled standard deviation. 
below a 2.5. In HS1 there were two teachers considerably above the mean for that school on the initial observation $(-X=1.72$, $S D=0.22$ ) while still indicating a poor implementation. Additionally, there were three teachers considerably below the mean $(-X=0.37, S D=0.25)$, in essence, no implementation. At the end of the study, teachers in HS1 were closely grouped around the mean $(-X=1.83, S D=0.42)$, indicating an overall poor implementation (see Table 2).

Student performance for HS1, as measured by state accountability tests, showed little change across the years. The statistics were obtained by first calculating the mean scores on the state accountability test for each longitudinal and matched group and the effect size was calculated using mean difference from inception to the final year of the project dividing the pooled standard deviation for both years. The longitudinal group $(\mathrm{N}=54)$ lost 6 due to attrition, the matched group $(n=19)$ lost 41 due to attrition. The results indicted a positive effect for reading. The project was not intended to impact reading (language arts). The longitudinal group exhibited increased reading scores (Cohen's $d=0.26$ ), while both mathematics and science scores remained consistently flat across those years (Cohen's $d$ $=-0.16,0.08)$ with an overall retention of 54 students out of the initial 60 students. The propensity score matched group showed improvement in mathematics and science (Cohen's $d$ $=0.34,0.22$ ), while scores in reading showed negative growth (Cohen's $d=-0.48$ ), but only 19 of the original 60 students remained in this group. Because the changes in reading scores were not a focus of this study, the differential results may be evidence that the trajectory was unrelated to the sustained PD. Because the selection criteria were highly useful for predicting retention in the other two cases, it was not readily apparent why the propensity score matched group in this school did not reflect similar retention as all the other groups. Therefore, the positive effects by the propensity score matched group were for a select group of students who remained. While there were no data to explain the attrition, it is possible that students who experienced a poor PBL implementation in Grade 9 had important differences in initial experiences as compared to those students who experienced virtually no implementation, or perhaps there may have been important teacher differences not measured by the observation instrument (see Table 3 ).

HS2. The average implementation to which raters were trained was a mean of 2.5. The teachers in HS2 $(n=25)$ demonstrated a level two implementation with mean scores clustered around 2.5 within the range of 2.0-3.0. In HS2, there were three teachers considerably above the mean for the school on the initial observation $(-X=1.79, S D=0.33)$; additionally, there were four teachers considerably below the mean $(-X=$ $1.09, S D=0.17$ ). By the end of the study, the teachers in this school exhibited similar variance to the start of the study except the mean had increased substantially $(-X=2.78, S D=0.42)$, indicating an overall average implementation (see Table 2).

The statistics presented here were computed in the same way as for HS1. HS2 student performance showed moderate gains across the years for mathematics (Cohen's $d=0.66$ ) and science (Cohen's $d=0.73$ ) but negative effects for reading (Cohen's $d=-0.34$ ), although no changes in reading were expected. The longitudinal group had an overall retention of 56 students out of the initial 60 students. The matched group showed modest negative effects for mathematics and reading (Cohen's $d=-0.23,-0.35$ ), respectively, and no effect for science (Cohen's $d=0.01$ ) with an overall retention of 57 students (see Table 3). Students in HS2 were likely to have experienced average fidelity of implementation from their teachers over the entire study.

HS2 had the greatest teacher attrition of the three schools. The principal replaced all but one teacher out of the entire mathematics department during summer of 2008. The principal replaced the teachers due to a lack of commitment to the innovation as well as other factors related to teaching performance. During the interview process a paramount concern was the new teachers' willingness to adopt an active and positive stance toward the innovation. These new mathematics teachers participated in the three-day summer PD and six make-up sessions during the fall of the first study school year and worked with their team during their school site professional learning communities.

HS3. A mean implementation of 3.5 with all indicators above 2.5 was considered a high implementation of the intervention or a level 3 implementation. HS3 typified this level of implementation with one teacher considerably above the mean for the initial observation $(-X=2.76, S D=0.41)$, indicating an average implementation; additionally, two teachers performed considerably below the initial mean $(-X=1.19, S D=$ 0.45), indicating a poor implementation, but by far HS3 demonstrated the highest level of implementation among the three schools. By the end of the study, teachers in HS3 exhibited much less variance as compared to the study start with the mean increasing considerably $(-X=3.6, S D=0.23)$, indicating a high implementation (see Table 2 ).

Longitudinal student performance showed impressive gains across the years for mathematics (Cohen's $d=1.41$ ) and science (Cohen's $d=2.03$ ) and a modest effect for reading (Cohen's $d=0.36$ ) with an overall retention of 53

Table 3. Mean STEM PBL enactments by observation category and school across years.

\begin{tabular}{|c|c|c|c|c|c|c|c|c|c|c|c|c|}
\hline \multirow[b]{2}{*}{ Category } & \multicolumn{4}{|c|}{ High School 1} & \multicolumn{4}{|c|}{ High School 2} & \multicolumn{4}{|c|}{ High School 3} \\
\hline & Y1 & Y2 & Y3 & Y4 & Y1 & Y2 & Y3 & Y4 & Y1 & $Y 2$ & Y3 & Y4 \\
\hline Structure & 0.46 & 1.53 & 1.65 & 1.44 & 1.01 & 1.28 & 2.01 & 2.93 & 0.076 & 1.28 & 3.20 & 4.04 \\
\hline Facilitation & 1.82 & 2.09 & 2.31 & 2.19 & 1.24 & 1.43 & 2.40 & 2.72 & 1.34 & 1.72 & 3.54 & 3.93 \\
\hline St. Part. & 1.74 & 2.72 & 2.88 & 2.65 & 2.01 & 2.25 & 2.45 & 2.34 & 2.44 & 2.30 & 2.67 & 3.38 \\
\hline Resources & 1.45 & 1.75 & 1.65 & 1.57 & 1.75 & 2.50 & 3.29 & 3.54 & 2.34 & 2.21 & 3.07 & 3.97 \\
\hline Assessment & 0.88 & 1.56 & 1.40 & 1.32 & 1.00 & 1.20 & 3.40 & 2.93 & 1.24 & 1.53 & 2.03 & 3.19 \\
\hline Learning environment & 2.01 & 3.30 & 2.53 & 1.78 & 2.09 & 2.21 & 3.02 & 2.74 & 1.98 & 1.76 & 3.45 & 3.58 \\
\hline
\end{tabular}


students of the initial 60 students (see Table 3). The matched group also showed important positive effects for mathematics and science (Cohen's $d=0.62,0.92$ ) and a negative effect for reading (Cohen's $d=-0.80$ ) with an overall retention of 55 . HS3 exhibited the greatest fidelity to the intervention, and after reducing variance on teaching performance in the second year, the teachers in this school consistently grew in fidelity. Furthermore, there was no teacher attrition in the STEM fields. The large growth in both student groups might account for two important differences at HS3. Students were likely to have had teachers with high fidelity for all three years of the study. Additionally, differences between the teachers were generally small, making differentiating between teachers' fidelity unimportant.

An important difference emerged in the variance between student scores. While the variance between the longitudinal and matched groups was nearly the same at the start of the study, the variance had decreased for the longitudinal group, perhaps indicating that teachers with the highest fidelity at the inception of the study helped to reduce within group variance as compared to teachers with a poor initial implementation. This is speculation, and other plausible explanations may exist for the decrease in student score variation.

\section{Qualitative results}

The qualitative data were based on two types of focus group interviews-mathematics and science professional learning communities within each high school for a total of six focus group interviews. Thus, there are qualitative data from each high school, but this was not done in a way to provide a comparison among the three schools, though there is a published, in-depth study of the school with the highest fidelity to the intervention and the best results (Huggins et al., 2011). Instead, the qualitative data will be used to present themes that emerged from analyzing all of the teacher focus groups conducted for both science and mathematics teachers in all three schools. These data were intended to provide some richness and depth to the effects found in the quantitative analyses. The main themes (see Table 4) that emerged from the qualitative analyses included teachers' (a) general experiences from using PBLs in their classrooms, (b) perceived changes in teaching methods drawn from using PBLs in their classrooms, (c) general experiences with professional learning communities, and (d) teachers' perceptions of the PD provided to them on PBLs and professional learning communities. Thus, these qualitative data do not address fidelity comparisons but the teachers' experience of doing project-based learning in this particular district context.

\section{Teachers' general experiences from using PBLs in their classrooms}

District wide, the teachers indicated that there were major positive effects and some significant challenges from implementing PBLs. The strongest positive effect that was reported (confirmed by five out of six focus groups) was that the PBLs increased student engagement. This result was particularly important because one of the major reported problems in diverse high schools is the lack of engagement of diverse urban students (National Research Council and Institute of Medicine, 2004). A second positive effect reported by three focus groups was that PBLs engaged students who were typically unengaged, another desired result. For example, one teacher stated, "I find that more students are getting involved in the lab. Some of those that would just sit off to the side in a regular lab that are relying on the lab partners to do the work actually got involved in the project." Similarly, another teacher in different group said, "[The PBLs] drew some interest from students who may not have been interested otherwise because you could say directly 'this relates to your project.' And then they would listen to the lesson a little more intently." This helps explain the first point, as it indicates that some of the increased student engagement likely came from engaging the typically disengaged students. A third positive effect reported by three focus groups was that PBLs increased the range of roles students could participate in by providing small group activities.

There were five more positive effects regarding PBLs that were supported by two focus groups: (a) real-world PBLs made learning more meaningful to students; (b) PBLs drew on a broader student skill set than did traditional teaching; (c) students took greater ownership of their learning; (d) teachers took a more facilitative role in the implementation of PBLs; and (e) PBLs improved teachers' relationships with their students. An example that illustrates the third positive effect of greater student ownership was that students became attached to their projects and their role in the project, such as contributing a drawing that illustrated their group's collaborative work. The teachers also reported that their students wanted to display their projects for other students and teachers to see. Thus, it can be observed that several of the positive effects reported by teachers related to greater student engagement, while other positive effects were related to pedagogical improvements.

The teachers also discussed some of the challenges encountered while implementing PBLs in their classrooms. The greatest challenge the teachers reported (supported by all six focus groups) was that some students lacked sufficient supporting knowledge or skills to complete the PBLs. One teacher stated,

Many of our students have a difficult time reading, and some of them don't understand what they're reading so if they're not

Table 4. Main themes from qualitative analyses.

\begin{tabular}{ll}
\hline Theme \# & Theme \\
\hline 1 & General experiences from using project-based learning in their classrooms \\
2 & Perceived changes in teaching methods drawn from using project-based learning in their classrooms \\
3 & General experiences with professional learning communities \\
4 & Teachers' perceptions of the professional development provided to them on project-based learning and professional learning communities \\
\hline
\end{tabular}


understanding what they're reading, then that's going to affect the way they're writing. They go hand in hand.

\section{Another teacher stated,}

Our kids are, generally speaking... seventy to eighty percent of our kids are behind where they should be mathematically... so PBLs are interesting, but trying to make it fit with all the stuff that they don't know... [for teaching science] makes it interesting.

The second greatest challenge to PBL implementation (reported by four focus groups) was that there was inadequate time to complete the PBLs. One teacher stated,

Ultimately, it just boils down to not having enough time. My kiddos go out there and, you know, like we've done a few projects now. But, the thing is I never feel like we've ever had the chance to really truly go into it, do it, and then do the follow up on it. I feel like we get halfway there, and we get the momentum going. And then, we have to go on to another thing. You know, it's never enough. A few days, two days, three days isn't enough to finish a complete project for most of my kiddos. We have to keep up with [curriculum].

Three focus groups brought up two additional challenges encountered in PBL implementation: (a) conflicts among students within their small groups (e.g., unequal work, personality conflicts) and (b) the PBL approach was a significant paradigm shift for students. Regarding the paradigm shift for students, teachers stated that students were so used to traditional instruction that adapting to a PBL-oriented classroom was difficult for them. One teacher pointed out that the students had experienced traditional instruction from kindergarten through middle school so it was difficult for them to accept a substantially different approach in high school. Finally, there were three additional challenges brought up by two focus groups: (a) PBLs were a pedagogical paradigm shift for teachers; (b) teachers reported problems with pacing PBLs; and (c) PBLs did not fit some students' learning styles. Regarding the pacing issue, one teacher stated,

One thing for me is... trying to know when I'm giving enough time versus too much time, whether the kids are just dragging their feet versus they're really working with the material. It's just very difficult for me to know when I need to say, "Okay this is a firm and hard deadline, and we're going to stick to it," versus "Okay. I can see everybody's struggling, so I'll give you guys one extra day or maybe, two extra days."

Thus, the teachers reported some challenges they faced in implementing PBLs and some that the students faced. It might be expected, however, that with more teacher and student experience in implementing and participating in PBLs, many of these challenges would dissipate.

\section{Teachers' perceived changes in teaching methods drawn from using PBLs in their classrooms}

The focus groups reported eight different ways that their teaching methods changed from implementing PBLs (see Table 5). Four focus groups said that implementing PBLs in their classrooms placed them in a more facilitative role and in less of a direct teaching or lecturing role. For example, one teacher said, "When kids ask me questions [about the PBL], I ask them, What does your team say? Go ask your teammates." And they are like, "oh, okay." Three focus groups reported that they used more real-world projects in their teaching, and three different focus groups reported that using PBLs in their classrooms promoted individual student accountability and ownership.

There were two categories under this theme reported by two focus groups, and three categories that were brought up by only one focus group. Two focus groups reported that the PBL process helped their students see that they knew more than they thought they did. The second category, which was

Table 5. Subthemes for Theme 1: General experiences from using project-based learning in their classrooms.

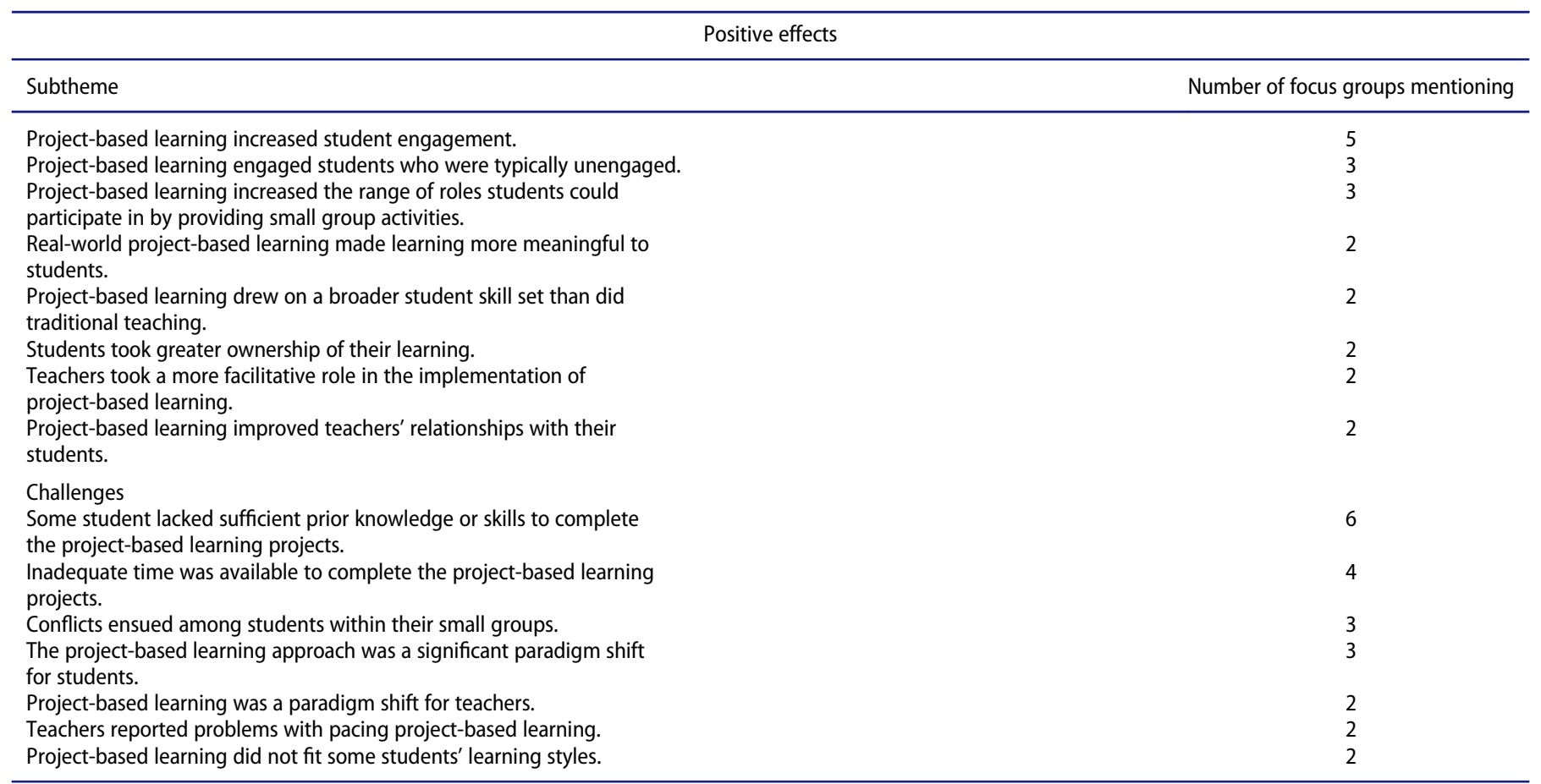


reported by two focus groups, was that PBLs gave the students more freedom to learn from their mistakes. The three categories that were reported by only one focus group included: (a) as teachers, they have learned that students "doing it themselves learn better"; (b) that they do less "drill and kill" in their classroom; and (c) PBLs provides an alternative teaching method for new teachers.

\section{Teachers' general experiences with professional learning communities}

Professional learning communities were an integral part of the PD the teachers received. The district supported the professional learning communities by providing one extra period per day for teachers to collaborate that were constructed around the research-based characteristics of professional communities, including shared values, reflective dialogue, deprivatization of practice, focus on student learning, and collaboration (Kruse et al., 1995). This period was an addition to the one individual planning period allotted to teachers. In the focus groups, the teachers were asked to discuss the positive and negative aspects of the professional learning communities.

Five of the focus groups reported that professional learning communities provided more time for the teachers to learn from each other (a specific goal of professional learning communities) and provided strong support for the development of their PBLs (e.g., McLaughlin \& Talbert, 2001). One teacher said, "Improvement in teaching strategies has occurred because of the collaboration between new and old teachers." Another teacher stated, "This has been my first year teaching chemistry, so without the [professional learning communities], I wouldn't have been able to improve with my kids, to teach, to complete everything because... .we help each other all the time. We talk. We share comments [and] concerns when we get together." Three focus groups reported two other categories: (a) time to plan together and (b) enhanced communication among teachers. Two focus groups reported that professional learning communities made teachers feel less isolated and supported new teachers in adopting the curriculum. Finally, four categories were reported by only one focus group. These categories included: (a) professional learning communities provided time to collectively diagnose students' strengths and weaknesses, (b) professional learning communities resulted in teachers being more attached to the success of their colleagues, (c) professional learning communities helped teachers become better at teaming, and (d) professional learning communities enabled more sharing of supplies and equipment.

Regarding negative aspects of professional learning communities, two categories were provided by three focus groups. First, three focus groups reported that school leaders sometimes interrupted professional learning community meetings. Additionally, three focus groups reported that some professional learning community time was not spent on discussion related to teaching and learning. Three categories were reported by two focus groups: (a) there was a need for more professional learning community time; (b) subject-focused professional learning communities did not provide time for interdisciplinary collaboration; and (c) group consensus was time consuming and perceived as sometimes more difficult than individual planning. For instance, one teacher commented on the need for interdisciplinary work, "I think the interdisciplinary thing is key because they've given within-subject matter, that common planning time, but we don't have that cross-subject matter."

\section{Teachers' perceptions of the PD provided to them on PBLs and professional learning communities}

There were many positive aspects of the PD reported, but most were brought up by only one focus group. Three focus groups reported that the opportunity to plan PBLs with the PD trainers was beneficial. Two focus groups reported that the opportunity to work with teachers from other schools during PD was also beneficial. Two focus groups also praised the trainers for the materials provided during the PD. Additionally, two focus groups reported that the teachers had received PD on how to work effectively in professional learning communities. The rest of the categories were provided by only one focus group each: (a) teachers praised the hands-on nature of the PD, (b) teachers appreciated the ability to readily turn their ideas into curriculum use, (c) teachers offered praise for specific PD trainers, (d) teachers reported that they liked the individual feedback they received from the $\mathrm{PD}$ trainers, (e) teachers said the $\mathrm{PD}$ was professionally done, (f) teachers reported that the trainers were willing to adapt to their feedback, $(\mathrm{g})$ teachers reported that the time provided within PD to develop guidelines for individual teacher teams was helpful, and (h) the initial training was viewed as beneficial for helping teachers to get started on working effectively in professional learning communities.

Regarding negative aspects of $\mathrm{PD}$, one theme was brought up by five focus groups, and this was a desire for more concrete examples of PBLs used in other schools. There were a range of other criticisms provided by two focus groups: (a) at times teachers felt evaluations of their individual PBLs were not given back quickly enough, (b) teachers reported that they needed more guidance during the first year of PBL implementation, and (c) some teachers felt they did not need follow-up professional learning community training.

\section{Discussion}

Without question, effectively bringing STEM into high school classrooms is a critically important issue (Kuenzi, 2008). However, there is very little research that investigates how this might be done and done in such a way that improves student learning (U.S. Department of Education, 2007), especially in mathematics and science, which are generally weak areas nationally (National Academies, 2007). Furthermore, there is a lack of research on STEM initiatives that are highly successful with diverse, urban high school students (Museus et al., 2011). This study may, thus, be the first that addresses all of these needed areas.

This study demonstrates that sustained and systematic highquality, research-based PD on STEM-oriented PBLs and professional learning communities could lead to major student learning gains, as measured by state accountability measures, when there was a high-quality implementation of the initiative. This latter finding is very important, as this study shows that low-quality implementation of a new initiative actually hurt student learning. This finding could be mediated through teacher content knowledge. However, we did not neither 
attempted to estimate this nor did we attempt to estimate whether mathematics and science teachers possessed sufficient pedagogical content knowledge to teacher their subjects. One reason we did not attempt to estimate either of these was because no deficiency was detected during the PD sessions nor during classroom observations. However, these do not preclude a lack of content knowledge as being responsible for a low implementation. It could be speculated that any new initiative, when poorly implemented, could actually degrade classroom instruction and concomitantly student learning. On the other hand, a moderately good implementation of PBL led to important gains, and a high-quality implementation led to substantial, even impressive gains in student learning. One lesson, then, may be to implement fairly well or not at all. However, the more crucial point is that high-quality, research-based PD on pedagogical improvements (i.e., the application of STEM PBLs, and on professional learning communities, both widely supported in the research literature; Englert \& Tarrant, 1995; Geier et al., 2008; Hollins et al., 2004) can lead to significant gains in student learning when the initiative is implemented with fidelity. This is a critical finding that has positive implications for any national or state efforts to successfully move STEM into diverse classrooms.

The findings in the present study also support what is replete in the research literature, that sustained, systematic high-quality, research-based PD can change teachers' classroom behaviors in ways that improve student learning (Cohen \& Hill, 2000; Czerniak et al., 2005; Loucks-Horsley et al., 2003; Saunders et al., 2009; Schneider et al., 2002). The caveat here is that all the teachers received the same $\mathrm{PD}$, the same classroom observations and classroom followup, and all wrote and implemented STEM PBL lessons. Why did only one school have a high level of implementation but perhaps more importantly, why did one school have such a low level of implementation? When considering teacher factors within school such as years in the school, degrees held, and proportion by gender were all similar. No school had out of field or teachers who were not highly qualified, terminal degrees, or presidential award winners for teaching. The school with the highest fidelity also had the lowest ratio of graduate degrees. While we do not have data from the entire pool of teachers, the most common graduate degree for a classroom teacher is counseling, library media, or administration. Few Texas teachers return to college to pursue graduate degrees in their content areas because there is no teacher ladder system that provides significant monetary or working condition incentives to earn it or after receiving it. Therefore, teachers tend to return to graduate school to earn a degree that will afford a job change. While $69 \%$ of the districts in Texas pay more to teachers with an advanced degree only $26 \%$ of teachers have earned one and the state average stipend after earning one is $\$ 1,137$ (Texas Association of School Boards and Texas Association of School Administrators, 2013). Few districts provide monetary or scheduling considerations for teachers who want to pursue a graduate degree. The most concerning is that the school with the highest weighted average for teaching in the same school had the lowest level of implementation. This leads to at least two interesting questions: (a) Does longevity in the same school breed complacency? and (b) Does familiarity breed contempt? For the first question, can a teacher who has been somewhere a long time have the clout or reputation to retain his or her belief structure and work ethic to buck a trend. Clearly, there were teachers with many years in that school and those with much fewer than weighted mean. Does this educator with the greatest longevity have the ability to mitigate or moderate the efforts of newer teachers? Assuming younger teachers have greater motivation is a slippery slope because they would lack important experiences with the community, the school, and their bag of tricks would also be somewhat limited to their preservice teacher program. For question two, when teachers and the administrators who oversee them have worked together for long periods of time is it possible that this familiarity breeds contempt. Not in an overtly negative way for them but for the educational process. Could administrators be more tolerant of successful teachers (teachers who have few discipline problems, low parent complaints, and are diligent with their paperwork) who choose not to implement a program or innovation, fail to confront them for fear that pushing them too hard may lead to discipline problems and parent complaints? The lack of fidelity is enigmatic, in that studying it would have required that we knew in advance that the school and its teachers were going to be low implementers.

This study helps to validate the literature on professional learning communities. This study showed that when professional learning communities have support from the administration and when professional learning are conducted based on a best-practices model, they could help change teachers' classroom behaviors and meaningfully improve student learning (e.g., Englert \& Tarrant, 1995; Hollins et al., 2004; Louis \& Marks, 1998). This research also showed that high-quality PD is effective within the context of an urban high school setting populated primarily by diverse students from low-income families. This finding has important implications for national and state educational policies and efforts to improve STEM-oriented learning for all students.

In HS2 it appears that initial experiences with better than average fidelity of implementation played an important role in student learning that was measurable and important at the end of the study. Again, though, the effects for reading scores were slightly negative. One possible reason for the negative effects for reading might have been that because of the strong districtwide focus on STEM, language arts teachers may have perceived that their subject was deemphasized. However, nothing associated with the intervention should have accounted for the negative effects. Another outcome evidenced in the longitudinal group, an arguably more important effect, $56 \%$ of the students passed the state minimal skills test in 2006-2007, while at the end of the study $92 \%$ passed in $2009-2010$ as compared to only $64 \%$ for the propensity score matched group.

The qualitative research in this study provides direction for issues that need to be considered as others try to introduce similar initiatives in urban education settings, although many of the findings were already supported by the research literature. In this regard, one of the findings that emerged from the focus groups, which is supported by the research literature, is the 
difficulty of learning a new pedagogical strategy or approach for both teachers and students (Marx et al., 1997; Maskit, 2011). Another finding that emerged from the focus groups is that the PD must be high quality to gain the support of teachers, but even then that support will not be $100 \%$. Thus, it is important for the PD providers to be receptive to feedback to improve PD (Klingner, 2004). Additionally, to make professional learning communities successful, the PD providers need to ensure that teachers and school leaders clearly understand characteristics of successful professional learning communities and understand how to implement and sustain these characteristics.

It is also important to address the limitations of the present study. This is but one study of three high schools in one diverse urban district with one group of PD providers simultaneously providing $\mathrm{PD}$ on one version of $\mathrm{PBL}$ and professional learning communities. Additional research needs to be conducted with variations on all of these components to determine what aspects of the innovation presented here are generalizable across different school contexts and providers, and with different initiatives. It may be that high-quality PD is the necessary component for success, or it may be that PBLs and professional learning communities, separately or integrated, are the key to success, or all three components may be necessary for success.

\section{Conclusion}

Success with STEM-oriented learning, especially with diverse urban high school students for whom the nation's schools are typically unsuccessful in any subject (National Research Council and Institute of Medicine, 2004), is critically important (National Academies, 2007). This study provides support for the utility of PBL and professional learning communities in raising the achievement of diverse urban high school students. This research shows it is possible to be successful in substantially improving student learning, when a high-quality initiative is given a high-quality implementation. This is good news in the face of much difficulty in efforts to improve student learning in STEM areas particularly among diverse, urban students. Nonetheless, this is only a single study conducted in one district. For this good news to grow, further research is needed that broadens the limited boundaries of what this research yielded. Further, this study is limited in its outcome measure not being solely aligned to the exact lessons taught, the PBLs designed by the teachers were done so with specific TAKS objectives in mind and comprised the learning objectives for the six-week period. Additionally, PBL instruction was not the only instruction conducted during any six-week period, however, that traditional instruction had not yielded sufficiently high growth as to create a ceiling effect in this study. Therefore, that additional instruction should not likely be considered as an important threat to validity.

\section{Acknowledgments}

The authors thank Charles M. Capraro, whose own personal perseverance and courage provided us all inspiration.

\section{Note}

1. For specific examples of PBL lessons, readers may refer to A Companion to Interdisciplinary STEM Project-Based Learning (Capraro, Capraro, Morgan, \& Sheurich, 2010).

\section{References}

Argyris, C., \& Schön, D. (1978). Organizational learning: A theory of action perspective. Reading, MA: Addison-Wesley.

Ashby, C. M. (2010). K-12 education: Many challenges arise in educating students who change schools frequently. Report to congressional requesters. GAO-11-40. Washington, DC: U.S. Government Accountability Office.

Berry, R. Q. III, Reed, P. A., Ritz, J. M., Lin, C. Y., Hsiung, S., \& Frazier, W. (2004). Stimulating students to improve science and mathematics achievement. The Technology Teacher, 64, 23-29.

Blumenfeld, P., Soloway, E., Marx, R., Krajcik, J., Guzdial, M., \& Palincsar, A. (1991). Motivating project-based learning: Sustaining the doing, supporting the learning. Educational Psychologist, 26, 369-398.

Bradley-Levine, J., Berghoff, B., Seybold, J., Sever, R., Blackwell, S., \& Smiley, A. (2010). What teachers and administrators "need to know" about project-based learning implementation. Paper presented at the annual meeting of the American Educational Research Association. Denver, Colorado. April, 2010.

Bransford, J. D., Brown, A. L., \& Cockling, R. R. (2000). How people learn: Brain, mind, experience, and school. Washington, DC: National Academy Press.

Bridges, E., \& Hallinger, P. (1996). Problem-based learning: A promising approach to professional development. In M. W. McLaughlin \& I. Oberman (Eds.), Teacher learning: New policies, new practices (pp. 145-160). New York, NY: Teachers College Press.

Buck Institute for Education. (2003). Project based learning handbook: A guide to standards-focused project based learning for middle and high school teachers. Oakland, CA: Wilsted \& Taylor.

Buysse, V., Sparkman, K. L., \& Wesley, P. W. (2003). Communities of practice: Connecting what we know with what we do. Exceptional Children, 69, 263-277.

Capraro, R. M., Capraro, M. M., \& Morgan, J. (Eds.). (2013). Project based learning: An integrated science technology engineering and mathematics (STEM) approach (2nd ed.). Rotterdam, the Netherlands: Sense.

Capraro, R. M., Capraro, M. M., Morgan, J., \& Scheurich, J. (Eds.). (2010). A companion to interdisciplinary STEM project based learning: For teachers by teachers. Rotterdam, the Netherlands: Sense

Capraro, R. M., \& Slough, S. W. (Eds.). (2008). Project-based learning: An integrated science, technology, engineering, and mathematics (STEM) approach. Rotterdam, the Netherlands: Sense.

Chin, C., \& Chia, L. (2006). Problem-based learning: Using ill-structured problems in biology project work. Science Education, 90, 44-67.

Cochran-Smith, M., \& Lytle, S. L. (1999). Relationships of knowledge and practice: Teacher learning in communities. Review of Research in Education, 24, 249-305.

Cohen, D. K., \& Hill, H. C. (2000). Instructional policy and classroom performance: The mathematics reform in California. Teachers College Record, 102, 294-343.

Colburn, A. (1998). Constructivism and science teaching. Fastback, 435, Bloomington, IN: Phi Delta Kappa Educational Foundation.

Cooper, R., \& Liou, D. D. (2007). The structure and culture of information pathways: Rethinking opportunity to learn in urban high schools during the ninth grade transition. The High School Journal, 91, 43-56.

Curtis, D. (2001). Real-world issues motivate students. Retrieved from http://www.edutopia.org/start-pyramid

Creswell, J. W. (2009). Research design: Qualitative, quantitative, and mixed methods approaches (3rd ed.). Thousand Oaks, CA: Sage.

Czerniak, C. M., Beltyukova, S., Struble, J., Haney, J. J., \& Lumpe, A. T. (2005). Do you see what I see? The relationship between a professional development model and student achievement. In R. E. Yager (Ed.), Exemplary science in grades 5-8: Standards-based success stories (pp. 13-43). Arlington, VA: NSTA Press. 
Darling-Hammond, L., \& McLaughlin, M. W. (1995). Policies that support professional development in an era of reform. Phi Delta Kappan, 76, 597-604.

Darling-Hammond, L., Wei, R. C., Andree, A., Richardson, N. \& Orphonos, S. (2009). Professional learning in the learning profession: A status report on teacher development in the United States and abroad. Palo Alto, CA: National Staff Development Council.

Dehejia, R. H., \& Wahba, S. (2002). Propensity score-matching methods for nonexperimental causal studies. The Review of Economics and Statistics, 84, 151-161.

Desimone, L. M., Porter, A. C., Garet, M. S., Yoon, K. S., \& Birman, B. F. (2002). Effects of professional development on teachers' instruction: Results from a three-year longitudinal study. Educational Evaluation and Policy Analysis, 24, 81-112.

Dunlap, J. C. (2005). The name assigned to the document by the author. This field may also contain sub-titles, series names, and report numbers. Changes in students' use of lifelong learning skills during a problem-based learning project. The entity from which ERIC acquires the content, including journal, organization, and conference names, or by means of online submission from the author. Performance Improvement Quarterly, 18, 5-33.

Dyer, S. K. (Ed.). (2004). Under the microscope: A decade of gender equity projects in the sciences. Washington, DC: AAUW Educational Foundation.

Englert, C. S., \& Tarrant, K. L. (1995). Creating collaborative cultures for educational change. Remedial and Special Education, 16, 325-336, 353.

Flexner, A. (1910). Medical education in the United States and Canada: A report to the Carnegie Foundation for the advancement of teaching. New York, NY: The Carnegie Foundation for the Advancement of Teaching.

Fortus, D., Krajcik, J., Dershimer, R. C., Marx, R. W., \& Mamlok-Naaman, R. (2005). Design- based science and real-world problem-solving. International Journal of Science Education, 27, 855-879.

Freudenberg, N., \& Ruglis, J. (2007). Reframing school dropout as a public health issue. Preventing Chronic Disease: Public Health Research, Practice, and Policy, 4, 1-11.

Garet, M. S., Porter, A. C., Desimone, L., Birman, B. F., \& Yoon, K. S. (2001). What makes professional development effective? Results from a national sample of teachers. American Educational Research Journal, 38, 915-945.

Geier, R., Blumenfeld, P. C., Marx, R. W., Krajcik, J. S., Fishman, B., Soloway, E., \& Clay-Chambers, J. (2008). Standardized test outcomes for students engaged in inquiry-based science curricula in the context of urban reform. Journal of Research in Science Teaching, 45, 922-939.

Gibson, M. A., \& Hidalgo, N. (2009). Bridges to success in high school for migrant youth. Teachers College Record, 111, 683-711.

Guskey, T. R., \& Yoon, K. S. (2009). What works in professional development? Phi Delta Kappan, 90, 495-500.

Hancock, V., \& Betts, F. (2002). Back to the future: Preparing learners for academic success in 2004. Learning and Leading with Technology, 29 (7), 10-14.

Hailey, C. E., Erekson, T., Becker, K., \& Thomas, M. (2005). National center for engineering and technology education. The Technology Teacher, $64,23-26$.

Hart, J. E., \& Lee, O. (2003). Teacher professional development to improve the science and literacy achievement of English language learners. Bilingual Research Journal, 27, 475-501.

Hedberg, B. (1981). How organizations learn and unlearn. In P. Nystrom \& W. Starbuck (Eds.), Handbook of organizational design (pp. 9-11). New York, NY: Oxford University Press.

Herzog, K. J. (2010). Bolstering a STEM pipeline in Ohio. Techniques: Connecting Education and Careers, 85, 26-29.

Holbrook, J. (2007). Project-based learning with multimedia. Retrieved from http://pblmm.k12.ca.us/PBGuide/WhyPBL.html

Holbrook, J., Rannikmae, M., \& Valdmann, A. (2014). Identifying teacher needs for promoting education through science as a paradigm shift in science education. Science Education International, 25(2), 4-42.

Hollins, E. R., McIntyre, L. R., DeBose, C., Hollins, K. S., \& Towner, A. (2004). Promoting a self-sustaining learning community: Investigating an internal model for teacher development. International Journal of Qualitative Studies in Education, 17, 247-264.
Hord, S. M. (1997). Professional learning communities: Communities of continuous inquiry and improvement. Austin, TX: Southwest Educational Development Laboratory.

Hord, S. M., \& Sommers, W. A. (2008). Leading professional learning communities: Voices from research and practice. Thousand Oaks, CA: Corwin.

Huggins, K. S., Scheurich, J. J., \& Morgan, J. R. (2011). Professional learning communities as a leadership strategy to drive math success in an urban high school serving diverse, low-income students: A case study. Journal of Education for Students Placed at Risk, 16, 67-88.

Hung, D., Tan, S. C., \& Koh, T. S. (2006). Engaged learning: Making learning an authentic experience. In D. Hung \& M. S. Kline (Eds.), Engaged learning with emerging technologies (pp. 29-48). Dordrecht, the Netherlands: Springer.

James, L. R., Demaree, R. G., \& Wolf, G. (1984). Estimating within group interrater reliability with and without response bias. Journal of Applied Psychology, 69, 85-98.

Johnson, C. C., Kahle, J. B., \& Fargo, J. D. (2007). A study of the effect of sustained, whole-school professional development on student achievement in science. Journal of Research in Science Teaching, 44, 775-786.

Johnson, K., Hays, C., Center, H., \& Daley, C. (2004). Building capacity and sustainable prevention innovations: A sustainability planning model. Evaluation and Program Planning, 27, 135-149. doi:10.1016/j. evalprogplan.2004.01.002.

Kilpatrick, W. H. (1918). The project method. Teachers College Record, 19, 319-335.

Klingner, J. K. (2004) The science of professional development. Journal of Learning Disabilities, 37, 248-244.

Krajcik, J. S., Blumenfeld, P. C., Marx, R. W., \& Soloway, E. (1994). A collaborative model for helping middle grade science teachers learn project-based instruction. The Elementary School Journal, 94, 483-496.

Kruse, S. D., Louis, K. S., \& Bryk, A. S. (1995). An emerging framework for analyzing school-based professional community. In K. S. Louis, S. D. Kruse, \& Associates (Eds.), Professionalism and community: Perspectives on reforming urban schools (pp. 23-44). Thousand Oaks, CA: Corwin Press.

Kuenzi, J. J. (2008). Science, technology, engineering and mathematics (STEM) education: Background, federal policy and legislative action. Washington, DC: Congressional Research Service.

Kvale, S., \& Brinkmann, S. (2009). Interviews: Learning the craft of qualitative research interviewing. Thousand Oaks, CA: Sage.

Lee, O., Buxton, C., Lewis, S., \& LeRoy, K. (2006). Science inquiry and student diversity: Enhanced abilities and continuing difficulties after an instructional intervention. Journal of Research in Science Teaching, 43, 607-636.

Lincoln, Y. L., \& Guba, E. G. (1985). Naturalistic inquiry. Newbury, CA: Sage.

Loucks-Horsley, S., Love, N. B., Stiles, K. E., \& Mundy, S. E. (2003). Designing professional development for teachers of science and mathematics. Thousand Oaks, CA: Corwin Press.

Louis, K. S., Kruse, S. D., \& Marks, H. M. (1996). Schoolwide professional community. In F. M. Newman \& Associates (Eds.), Authentic achievement: Restructuring schools for intellectual quality (pp. 179-203). San Francisco, CA: Jossey-Bass.

Louis, K. S., \& Marks, H. M. (1998). Does professional learning community affect the classroom? Teachers' work and student experiences in restructuring schools. American Journal of Education, 106, 532-575.

Lowell, L. B., \& Salzman, H. (2007). Into the eye of the storm: Assessing the evidence on science and engineering education, quality, and workforce demand. Washington, DC: Urban Institute.

Marshall, C., \& Rossman, G. B. (2006). Designing qualitative research (4th ed.). Thousand Oaks, CA: Sage.

Marx, R. W., Blumenfeld, P. C., Krajcik, J. S., \& Soloway, E. (1997). Enacting project-based science. The Elementary School Journal, 97, 341-358.

Maskit, D. (2011). Teachers' attitudes toward pedagogical changes during various stages of professional development. Teaching and Teacher Education, 27, 851-860.

McLaughlin, M., \& Talbert, J. (2001). Professional communities and the work of high school teaching. Chicago, IL: The University Press.

Miles, M. B., \& Huberman, M. (1994). Qualitative data analysis: An expanded sourcebook (2nd ed.). Thousand Oaks, CA: Sage. 
Morrison, G. M., \& Cosden, M. A. (1997). Risk, resilience, and adjustment of individuals with learning disabilities. Learning Disability Quarterly, 20, 43-60.

Moyer-Packenham, P. S., Kitsantas, A., Bolyard, J. J., Huie, F., \& Irby, N. (2009). Participation by STEM faculty in mathematics and science partnership activities for teachers. Journal of STEM Education, 10, 1-20.

Museus, S. D., Palmer, R. T., Davis, R. J., \& Maramba, D. (2011). Racial and ethnic minority students' success in STEM Education. ASHE Higher Education Report. San Francisco, CA: Jossey-Bass.

Nadelson, L. S., Callahan, J., Pyke, P., Hay, A., Dance, M., \& Pfiester, J. (2013). Teacher STEM perception and preparation: Inquiry-based STEM professional development for elementary teachers. The Journal of Educational Research, 106, 157-168.

National Academies. (2007). Rising above the gathering storm: Energizing and employing America for a brighter economic future. Washington, DC: National Academies Press.

National Research Council. (2013). Next generation science standards: For states, By states. Washington, DC: The National Academies Press.

National Research Council and Institute of Medicine. (2004). Engaging schools: Fostering high school students' motivation to learn. Washington, DC: The National Academies Press.

National Governors Association Center for Best Practices, Council of Chief State School Officers. (2010). Common core state standards mathematics. Washington DC: Author.

No Child Left Behind Act of 2001, Public Law No. 107-110, 115 Stat. 1425, 2002.

Noyes, W. (1909). Ethical values of the manual and domestic arts. Proceedings of the Northern Illinois Teachers' Association, 6-17.

Patton, M. Q. (2002). Qualitative research and evaluation methods (3rd ed.). Thousand Oaks, CA: Sage.

Penuel, W. R., Fishman, B. J., Yamaguchi, R., \& Gallagher, L. P. (2007). What makes professional development effective? Strategies that foster curriculum implementation. American Educational Research Journal, 44, 921-958.

Phillips, J. (2003). Powerful learning: Creating learning communities in urban school reform. Journal of Curriculum and Supervision, 18, 240-258.

Polman, J. L. (2000) Designing project-based science inquiry connecting learners through guided inquiry. New York, NY: Teacher's College Press.

Resnick, L. B., \& Hall, M. W. (1998). Learning organizations for sustainable education reform. Daedalus, 127, 89-118.

Rodgers, M. A. P, Cross, D. I., Gresalfi, , Trauth-Nare, A. E., \& Buck, G. A. (2011). First year implementation of a project-based learning approach: The need for addressing teachers' orientations toward learning. International Journal of Science and Mathematics Education, 9, 893-917.

Satchwell, R. E., \& Loepp, F. L. (2002). Designing and implementing an integrated mathematics, science, and technology curriculum for the middle school. Journal of Industrial Teacher Education, 39, 41-66.

Saunders, W. M., Goldenberg, C. N., \& Gallimore, R. (2009). Increasing achievement by focusing grade-level teams on improving classroom learning: A prospective quasi-experimental study of Title I schools. American Educational Research Journal, 46, 1006-1003.

Schneider, R. M., Krajcik, J., Marx, R. W., \& Soloway, E. (2002). Performance of students in project-based science classrooms on a national measure of science achievement. Journal of Research in Science Teaching, 39, 410-422.

Scott, C. E. (2009). A comparative case study of the characteristics of science, technology, engineering, and mathematics (STEM) focused high schools. Fairfax, VA: George Mason University.

Senge, P. M. (1990). The fifth discipline: The art and science of the learning organization. New York, NY: Doubleday.

Shadish, W., Cook, T., \& Campbell, D. (2012). Experimental and quasiexperimental designs for generalized causal inference. New York, NY: Houghton Mifflin
Siverman, D. (2010). Doing qualitative research (3rd ed.). Thousand Oaks, CA: Sage.

Smylie, M. A., Allensworth, E., Greenberg, R. C., Harris, R., \& Luppescu, S. (2001). Teacher professional development in Chicago: Supporting effective practice. Chicago, IL: Consortium on Chicago School Research.

Stearns, L. M., Morgan, J., Capraro, M. M., \& Capraro, R. M. (2012). The development of a teacher observation instrument for PBL classroom instruction. Journal of STEM Education: Innovations and Research, 13 (3), 25-34.

Strobel, J., \& van Barneveld, A. (2009). When is PBL more effective? A meta-synthesis of meta-analyses comparing PBL to conventional classrooms. Interdisciplinary Journal of Problem-based Learning, 3(1). Available at: http://dx.doi.org/10.7771/1541-5015.1046

Sungur, S., \& Tekkaya, C. (2010). Effects of problem-based learning and traditional instruction on self-regulated learning. Journal of Educational Research, 99, 307-320.

Supovitz, J. A., \& Turner, H. M. (2000). The effects of professional development on science teaching practices and classroom culture. Journal of Research in Science Teaching, 37, 63-980.

Talbert, J. E., \& McLaughlin, M. W. (2002). Professional communities and the artisan model of teaching. Teachers and Teaching: Theory and Practice, 8, 325-343.

Texas Higher Education Coordinating Board \& Texas Education Agency. (2009). Texas college and career readiness standards. Austin, TX: Author.

Texas Association of School Boards and Texas Association of School Administrators. (2013). Salaries and benefits in Texas public schools teacher report. Austin, TX: Author. Retrieved from http://www.tasb.org/ services/hr_services/salary_surveys/documents/tchr_highlights_landing. pdf

Texas Education Agency. (2013). Texas essential knowledge and skills for mathematics chapter 111. Retrieved from http://ritter.tea.state.tx.us/ rules/tac/chapter111/ch111c.html

Thurston, R. H. (1891). The scientific basis of belief. The North American Review, 181-192.

Thurston, R. H. (1892). The next great problems of science. The Forum, xiv, 42-50.

Torp, L., \& Sage, S. M. (1998). Problems as possibilities. Alexandria, VA: ASCD. degree attainment. Journal of Education for Students Placed at Risk, 12, 243-270.

Toulmin, C. N., \& Groome, M. (2007). Building a science, technology, engineering and math agenda. Washington, DC: National Governors Association.

U.S. Department of Education. (2007). Report of the academic competitiveness council. Washington, DC: Author.

Wei, R. C., Darling-Hammond, L., \& Adamson, F. (2010). Professional development in the United States: Trends and challenges. Dallas, TX: National Staff Development Council.

Wilhelm, J., Sherrod, S., \& Walters, K. (2008). Project-based learning environments: Challenging pre-service teachers to act in the moment. The Journal of Educational Research, 101, 220-233.

Wirkala, C., \& Kuhn, D. (2011). Problem-based learning in K-12 education: Is it effective and how does it achieve its effects? American Education Research Journal, 48, 1157-1186.

Wolf, M. A. (2008). High schools: An equation that works. T.H.E. Journal, $35,24-26$.

Yoon, K. S., Duncan, T., W.-Y., Lee, S., Scarloss, B., \& Shapley, K. L. (2007). Reviewing the evidence on how teacher professional development affects student achievement. Washington, DC: U.S. Department of Education, Institute of Education Sciences. National Center for Education Evaluation and Regional Assistance, Regional Educational Laboratory Southwest. Retrieved from http://ies.ed.gov/ncee/edlabs/regions/southwest/ pdf/rel_2007033_sum.pdf 